\title{
Eulogy for a soldier of freedom, October 18, 2014
}

\author{
Stewart Burns \\ Son of James MacGregor Burns, Civil rights historian and biographer of Martin Luther King Jr, Professor \\ of Ethical and Creative Leadership and Martin Luther King Jr Studies at Union Institute \& University, \\ Cincinnati, OH, USA
}

Public memorial service for James MacGregor Burns, October 18, 2014, Thompson Memorial Chapel, Williams College, Williamstown, MA, USA

This chapel has special meaning for me not only because my father was required to attend weekly chapel service here when he was a Williams undergrad in the late 1930s, and I have worshipped here many times myself, but when I was 12 years old, I heard Dr Martin Luther King Jr preach from this pulpit, the only time I met the man whose life and leadership I became immersed in, as my father had become immersed in the life and leadership of Franklin D. Roosevelt in a different time.

My formal education began when I was four, when my father took me to my first day of kindergarten at the old Grant School. When he left, he said to me, 'kindergarten means a child's garden.' As both he and my mother grew luscious gardens at our home at the bottom of Park Street, a child's garden was where I wanted to be.

On my sixth birthday my father gave me a wooden desk he had built for me over many weeks, hiding away in an attic room in the evenings. I guess I had spent too much time, when he was away, typing stories on his Royal electric typewriter in his study and borrowing desk supplies that I kept. He knew that I needed a desk of my own.

My father always loved to tell the story of the evening in the 1950s when Senator John F. Kennedy came to our home on Park Street to fetch him for a campaign event they were sharing. Jim knew that his friend Jack Kennedy was always impatient and rushed. But he wanted his two little boys, my older brother David and me, to wave to the senator from our porch. When Kennedy's limousine pulled into our driveway, Jim greeted him and asked if he would wave to us up on the porch. 'Bring 'em on down!' the senator called out. So David and I ran down the lawn in our pajamas to be greeted by the next president of the United States.

Jim brought our family to visit Senator Kennedy and his wife in their home in Georgetown in the heady spring of 1960. Sitting next to him, he in his rocking chair, I asked him if he had any hobbies. He told me he loved to sail, but that he didn't have much time for that anymore.

My father's life became entwined with John Kennedy's, as did mine, in my childhood dreams. When Kennedy was running for re-election in 1958 he actively campaigned with and for my father, the Democratic candidate for Congress from this rock-solid Republican district - how times have changed! Years later Jim recalled that, already a prominent political scientist at Williams with his first volume biography of FDR published to great acclaim, finalist for a Pulitzer, and a best seller, he decided he wanted to become more of a political activist. And he wanted to put into practice his deep knowledge of political campaigns and electioneering. 
Not enough, for him, to serve as a Democratic delegate to four Democratic national conventions, to head the Massachusetts Americans for Democratic Action, to chair the Massachusetts Commission Against Discrimination, and to struggle for decades to democratize and vitalize both the Massachusetts and national Democratic parties. He passionately believed that the only hope to bring real lasting freedom and security to Americans was through a progressive Democratic party, fully inclusive; enacting essential Congressional reforms; and, of course, great leadership from top to bottom.

My parents met organizing Harvard and Radcliffe students for a winning Congressional candidate in 1940. Four years earlier, as a Williams student doing community engagement, he campaigned single-handedly for FDR's re-election in North Adams, MA, driving a sound truck in the pouring rain. Really from the beginning of his academic career, Jim Burns served as an exemplar of the activist scholar. That perhaps is his most important legacy to me and many others, as well as to the academic world.

John Kennedy was re-elected to the Senate by a vast margin in 1958. My father was defeated - badly damaged, savaged, by his Democratic primary opponent who brought McCarthyism, which my father had always fought, to western Massachusetts, publicly calling my father a communist - an atheistic communist - and getting the Catholic hierarchy to follow suit. Apparently well-heeled industrialists in the Berkshires and beyond did not like Jim's support of organized labor when the local textile mills such as Berkshire Hathaway, Warren Buffett's first investment, were shutting down or moving to the non-union South and overseas, throwing thousands of local workers out on the streets.

Jim always told us to 'think of others.' He taught us the virtue of social responsibility, even if that sometimes trumped personal virtue. I'll never forget one hot summer day when my brother and I were trying to help our father combat the plague of Japanese beetles that were his garden's enemy and that he fought with pesticides. David and I thought a better way to kill the beetles would be to set them on fire in a frying pan. When my father, laboring in his garden, saw what we were doing, he ran down to us, kicked over the frying pan, and yelled angrily: 'You never kill for sport!' This decorated combat veteran, who had killed Japanese soldiers in the US invasions of Guam, Saipan, and Okinawa. That wasn't for sport.

As Senator Kennedy fired up his presidential campaign in 1959, he asked Jim to join his senior staff in Washington, to groom him for the White House post later taken by Arthur Schlesinger Jr of Harvard. At this point my father, worn out and depressed by his defeat, needed a break from activism. He turned down the offer. He decided instead to write the first biography of JFK. But upon completing the manuscript he ran into trouble with JFK's inner circle, and even with Jackie Kennedy, because the biography, while largely salutary, was a bit more critical than Kennedy's people had expected for the 1960 campaign. After reading the manuscript, Mrs Kennedy wrote him in longhand in late 1959: 'I think you underestimate him.... You are like him in many ways - an intellectual who has gone into politics. You know the hard parts and the pitfalls. Can't you see that he is exceptional?'

But after intense pressure and grueling face-to-face sessions with Ted Sorensen (JFK's chief adviser and speechwriter), Jim refused to make the change they most wanted: his question at the tail end about whether JFK would rise to the level of passionate and courageous moral leadership that the nation demanded, above all to eliminate the threat of thermonuclear war.

Jim, courageously standing his ground and preserving his intellectual integrity, brought about a rift with JFK's inner circle, though not with President Kennedy himself, who met with him a number of times in the White House. 
But Jim did not attend JFK's inauguration, and when the President returned to Boston in May 1961 for a gala homecoming birthday celebration, Jim asked me, his politically precocious 12 -year old, to take his place. I had the honor of sitting at the seat reserved for the poet Robert Frost, who was sitting on the dais with the President - my job to guard the legendary poet's hat, coat, and cane. I covered the event for the North Adams Transcript. Later that same year, in December 1961, my father arranged for me to ride with Ted Kennedy from Williams College to North Adams, where I sat with Jim in the smoke-filled back room of a bar where Ted Kennedy first announced that he was running for his brother's Senate seat.

I'm sure my father was proud of me for my political interests, which included getting involved in the Ban the Bomb movement in eighth grade, but apparently he worried that I was going overboard. After I ran away from home at age 13 to begin a new life in New York City, he wrote to his war buddy, novelist Edmund Love, who took care of me in the Big City, that he wondered if I should see a psychiatrist because of my dream of becoming president. Years later, my mother told me that when Jim was courting her, he expressed to her his own determination to become president.

Jim did not become president - except of two major academic associations, the American Political Science Association and the International Society for Political Psychology, and co-founder of the thriving International Leadership Association - but he influenced the presidencies of both JFK and LBJ, especially with his extraordinary work of 1963, Deadlock of Democracy, which is even more compelling today than in the 1960s.

President Johnson seemed determined to prove him wrong. Just a week after JFK's assassination he prodded the Republican leaders of Congress to pass civil rights and other key legislation. 'They've got the MacGregor Burnses and the rest of them writing about the Congress,' LBJ complained to them. 'There is some merit to the things they are saying.' He exclaimed to GOP congressman Gerald Ford: 'I was getting ready to tell MacGregor Burns he's right about the Congress - they couldn't function.'

Later LBJ invited Jim to the White House a number of times, trying to seduce him into becoming his biographer. At a private upstairs dinner with LBJ and his family in December 1967, in a White House under siege, trying to make conversation my father reported to the President that all four of his children had taken part in the March on the Pentagon in October, and that one had gotten arrested. That went down like a lead balloon. The grim President did not seem to appreciate it.

Several months later the son who got arrested and jailed decided to openly resist the draft as an act of Gandhian civil disobedience, which the son himself reported in a letter to the President.

Resisting the draft and leaving Columbia University to organize protest against the Vietnam War was, for my father, going too far - but despite his fears, and despite his own support for Johnson's war, he always supported my constitutional right to protest nonviolently, and my commitment to this moral cause even if it led me to federal prison. A handful of times I phoned my father from jail after nonviolent protests; he got used to it.

Despite my devotion to politics, albeit increasingly radical politics, my personal relationship with my father in those days was fairly remote. As a serious workaholic he was driven by powerful personal ambition - each success feeding the longing for further success.

Before and after I moved out to the Bay Area to join the Movement, Jim and I had fierce, highly emotional but respectful debates, especially at dinner parties, about the Vietnam War. Despite our differences, he invited me to speak jointly with him at 
Miss Hall's School on the historic antiwar Moratorium in October 1969. Although it turned out that he was understandably misinformed about US policy in Vietnam, the crux of our disagreement was over political freedom versus economic justice, freedom of speech versus freedom from want. I prioritized the latter. He prioritized the former. In hindsight I have to admit that, while he was woefully deceived about American motives and about the political repression in South Vietnam, I was mistaken about the commitment of the Vietnamese communists to meeting human needs.

Why this debate about political freedom versus social justice matters is that despite what I felt at the time to be Jim's myopic Cold Warrior stance, especially while LBJ was still president - this mindset came right out of Jim's World War II experience - I realized later that he was actually listening carefully to my dissenting views, which I'm sure troubled him, even though he fully supported my right to express them.

To grandly oversimplify a complex process of intellectual transformation, I would claim that the pre-eminent leadership philosophy that Jim produced in the 1970s, conveyed in his classic book Leadership (1978), of which I wrote a chapter, was essentially the fruit of Jim's agonistic struggle to make sense of the 1960s, the tumultuous time that turned his own life upside down and bewildered and mystified him. To make a long intellectual saga short, he ultimately realized that his longtime preoccupation with political process, and that of liberalism and political science as a whole - with the process of governance - had cut him off from the whole substantive realm of human needs.

And so over the next several years he developed an extraordinarily influential philosophy of leadership, and midwifed the whole new interdisciplinary field of leadership studies, grounded for him in the fundamental imperative of meeting human needs and wants - a process through which, as he had learned from the movements of the 1960s, people from the grassroots, commonly called the followers, must play a decisive, indispensable role, the role of leadership.

And so his emerging leadership philosophy revolved around leaders acting as followers and so-called followers acting as leaders - leaders and followers continuously trading places, taking turns. That followership and leadership were utterly and inextricably interdependent. In the process my father, who was so adept at manipulative transactional leadership (both as a father and as a politician) placed into the American lexicon forever the concept of transformational leadership.

Transformational leadership was his language for envisioning and evaluating leadership, by individuals or by groups, that struck a sturdy middle path between incremental or cosmetic change on the one hand - mere tinkering - and violent revolution or warfare on the other hand, which he had touched firsthand and hated. Dr King explored this dynamic middle ground in his 'Letter from Birmingham Jail' (1963) and elsewhere. Radical reform or radical democracy that goes to the roots of the problem.

We would-be leadership scholars and practitioners still have the task ahead of defining and comprehending transformational leadership to help make it more realizable. Currently, transforming or transformational leadership is not a theory. It is a moral vision. Jim Burns made a great start in conceptualizing and promoting it.

During all of this tumult of the 1960s and 1970s, and despite my living in California, I was able to benefit from the mentoring role that my father played with many of his students and colleagues, including a lot of you here today.

Shortly after I returned my draft card to President Johnson, I began a long-term collaboration with Jim that culminated two decades later in our co-authoring a book on struggles for rights in America, called A People's Charter (1991). Our collaboration started with him asking me to research and write sections of his wartime biography 
of FDR, The Soldier of Freedom (1970), about harnessing science and technology for the war effort, and the development of the atomic bomb - which could not have been more apt because of my longtime fear of and opposition to nuclear weapons.

In conclusion, when Jim called himself a 'leadership guy' - as he emphasized in the film about him, A Burning Fire, made by Deborah Schneer - for him, leadership was never merely an academic exercise. This was partly because he had faced a great deal of adversity in his life, including losing his two brothers to tragedies in the prime of their lives, and told me once that 'I don't deal well with adversity' - because he was always astonished, transported, and uplifted when leaders like FDR and Eleanor Roosevelt and Nelson Mandela were able to lead courageously in the face of overwhelming personal and political adversities. He knew how tough moral leadership was, actually living out one's deepest values, rather than just writing and preaching about them, and how rare it was. He perhaps glorified moral leadership in others because he knew how high the bar was, and he wasn't able to attain it himself.

Jim did not grow up in poverty and never knew it first hand, though he and his two brothers were raised by a single mom during the Depression, on their dad's child support, and lived on a shoestring. But in the final two decades of his long life, his primary mission, besides seeking a general theory of leadership akin to Marx's theory of capitalism or Einstein's theory of relativity, was not just to advance leadership in theory and practice but to apply leadership to abolishing poverty at home and around the globe. I had the privilege of partnering with him and Georgia Sorenson in creating the Global Poverty Leadership Initiative out of the Burns Academy of Leadership at the University of Maryland. Neither his quixotic quest for a general theory of leadership, nor our effort with the GPLI to nurture transformational grassroots leadership to overthrow African poverty succeeded.

What is the legacy that Jim Burns leaves for us? To never ever give up fighting to make the world better, to make the world survivable, to free people from want and deprivation, to apply democratic leadership to the pursuit of life, liberty, and the pursuit of happiness in our troubled nation and in our chaotic world. All of this as the moral equivalent of war, the moral alternative to war. To take our citizenship seriously and to live our lives as responsible citizens. That vital and virtuous and active citizenship, whether as leaders or followers or both combined, is the only answer to our growing storm of crises; and that citizenship must be learned. That the primary purpose of education, especially higher education, and most especially of a liberal arts college like Williams, is to teach citizenship education, all of us learning together that we all must strive to be leaders, even perhaps transformational leaders, no matter the odds, no matter the cost, if we want to achieve liberty and justice for all, or merely to survive. The alternative is unspeakable.

\section{REFERENCES}

Burns, James MacGregor (1963), The Deadlock of Democracy: Four-Party Politics in America, New York: Prentice-Hall.

Burns, James MacGregor (1970), Roosevelt: The Soldier of Freedom, New York: Harcourt Brace.

Burns, James MacGregor (1978), Leadership, New York: Harper \& Row.

Burns, James MacGregor and Stewart Burns (1991), A People's Charter: The Pursuit of Rights in America, New York: Knopf.

King, Martin Luther, Jr (1963), 'Letter from Birmingham Jail,' in Martin Luther King Jr, Why We Can't Wait, New York: Harper. 